\title{
MOTIVASI MAHASISWA USIA DEWASA MENGIKUTI PERKULIAHAN PADA PROGRAM STUDI PENDIDIKAN GURU PAUD DI FKIP UNINUS BANDUNG
}

\author{
Agus Ruswandi \\ Program Studi Pendidikan Guru PAUD Fakultas Keguruan dan Ilmu Pendidikan \\ Universitas Islam Nusantara \\ Email: agus.ruswandi@fkip-uninus.ac.id
}

Received August 2018, Accepted September 2018, Published October 2018

\begin{abstract}
This research is based on data from observation data of students of PG PAUD Uninus Bandung, which in conclusion about $40 \%$ of students of PG PAUD study program from the age side including middle age or other term is included in middle age. This condition attracts the attention of researchers so it is important to examine the background of students, motivation, goals and reasons of the students of the adult age group to attend the lectures in the PG PAUD Uninus FKIP. It is expected to obtain data for the stakeholders both at the level of Prodi, Faculty and University level. The method used in this research use descriptive analytical research method with qualitative approach. This method is supported by data collection techniques such as observation, documentation and interviews. The sample of this research is students of PG PAUD Uninus FKIP study program which is in the adult age range or about 25 and up to 60 years old. Technique of data analysis this research use three step analysis, that is data reduction, data display and data verification. The expected output of this research is in the form of scientific articles published in accredited national journals. The results showed that adult students who attended lectures at Prodi PG PAUD mostly aged between 51 to 55 years from the employment side of most of the students is a non-civil servant or honorary teachers and most have not been certified. adult students attending or continuing lectures in Prodi PG PAUD, among others, because the demands of their professions as PAUD teachers for the benefit of linearity or for students who have not previously had a diploma equivalent to some other scholars who have civil servants but the diploma is not linear with PAUD so that they have to go to college or PAUD field so that the diploma in accordance with the profession. The results conclude that economic factors are not the dominant factor for students to follow or continue their lectures in the area of early childhood is more dominated by linearity with their work not because of economic factors. As for economic reasons, certification. or civil servants that only a small part of one of the factors of adult students continue studying in Prodi PG PAUD.
\end{abstract}

Keywords: Motivation, student, adult age, college, PG PAUD.

\begin{abstract}
Abstrak: Penelitian ini berdasarkan pada data hasil observasi data mahasiswa program studi PG PAUD FKIP Uninus Bandung, yang pada kesimpulannya sekitar 40\% mahasiswa prodi PG PAUD dari sisi usia termasuk pada usia dewasa madya atau istilah lain adalah termasuk pada usia paruh baya. Kondisi ini menarik perhatian peneliti sehingga menganggap penting untuk diteliti mengenai latar belakang mahasiswa, motivasi, tujuan serta alasan para mahasiswa kelompok usia dewasa untuk mengikuti perkuliahan di program studi PG PAUD FKIP Uninus. Hal ini diharapkan bisa mendapatkan data untuk para pemangku kebijakan baik di tingkat Prodi, Fakultas Maupun tingkat Universitas. Metode yang digunakan dalam penelitian ini mengguakan metode penelitian deskriptif analistis dengan pendekatan kualitatif. Metode ini didukung oleh teknik pengumpulan data yaitu observasi, dokumentasi dan wawancara. Sampel penelitian ini adalah mahasiswa program studi PG PAUD FKIP Uninus yang berada pada rentang usia dewasa atau sekitar 25 sampai 60 tahun. Teknik analisis data penelitian ini menggunakan tiga langkah analisis, yaitu reduksi data, display data dan verifikasi data. Luaran yang diharapkan dari penelitian ini adalah berupa artikel ilmiah yang dimuat pada jurnal nasional terakreditasi. Hasil penelitian menunjukkan bahwa mahasiswa usia dewasa yang mengikuti perkuliahan di Prodi PG PAUD sebagian besar berusia antara 51 sampai 55 tahun dari sisi kepegawaian sebagian besar mahasiswa adalah berstatus guru non PNS atau honorer dan sebagian besar belum tersertifikasi. mahasiswa usia dewasa mengikuti atau melanjutkan perkuliahan di Prodi PG PAUD antara lain karena tuntutan profesi mereka sebagai guru PAUD baik untuk kepentingan linieritas atau bagi mahasiswa yang sama sekali sebelumnya belum memiliki ijazah setara sarjana sebagian lainnya guru yang sudah PNS tetapi ijazahnya tidak linier dengan bidang PAUD sehingga mereka harus melanjutkan kuliah ke jenjang atau bidang PAUD agar agar ijazahnya sesuai dengan profesinya. Hasil penelitian menyimpulkan bahwa faktor ekonomi tidak menjadi faktor yang mendominasi alasan mahasiswa mengikuti atau melanjutkan perkuliahan di bidang PAUD mereka lebih didominasi oleh keperluan linieritas dengan pekerjaannya masing-masing bukan karena faktor ekonomi. Adapun alasan ekonomi, sertifikasi, atau PNS itu hanya sebagian kecil saja menjadi salah satu faktor mahasiswa usia dewasa melanjutkan perkuliahan di Prodi PG PAUD.
\end{abstract}

Kata Kunci: Motivasi, mahasiswa, usia dewasa, kuliah, PG PAUD 


\section{PENDAHULUAN}

Perguruan tinggi merupakan salah satu sarana dalam penyelenggaraan dan pengembangan pendidikan yang dapat meningkatkan mutu kehidupan masyarakat, bangsa dan negara. Dengan banyaknya mahasiswa yang termotivasi untuk kuliah di perguruan tinggi masyarakat menaruh harapan mampu meningkatkan kualitas hidup manusia.

Terdapat banyak perguruan tinggi yang mempunyai program S1 di Indonesia. Perguruan tinggi dapat berbentuk akademi, politeknik, sekolah tinggi, institut atau universitas. Kemampuan untuk memperoleh mahasiswa tergantung dari penyampaian informasi atau promosi tentang perguruan tinggi yang bersangkutan. Perguruan tinggi sebagai penyedia produk berupa jasa pendidikan harus mampu mengenali target pasar yang menjadi sasarannya.

Program Studi Pendidikan Guru PAUD merupakan salah satu program studi pada Fakultas Keguruan dan Ilmu Pendidikan Universitas Islam Nusantara di Kota Bandung Jawa Barat. Program studi ini berdiri sejak tahun 2011 melalui SK Ijin Operasional dengan Nomor SK Izin Operasional 99/E/O/2011 pada tanggal 6 Mei 2011.

Berdasarkan perkembangannya, Program Studi PG PAUD termasuk program studi yang peminatnya sangat banyak untuk ukuran program studi baru pada saat itu. Berdasarkan data pada program studi PG PAUD tercatat pada tahun 2011 pendaftar mahasiswa baru yang lolos ujian masuk sebanyak 192 mahasiswa untuk 4 rombel perkuliahan. Pada tahun berikutnya tahun 2012 tercatat jumlah pendaftar sebagai mahasiswa baru program Studi PG PAUD sebanyak 245 mahasiswa. Hal ini merupakan jumlah yang cukup bagus dari sisi jumlah. Dengan jumlah ini program studi PG PAUD termasuk program studi PG PAUD dengan jumlah mahasiswa terbanyak kedua setelah program studi Pendidikan Luar Biasa (PLB) pada FKIP Uninus Bandung.
Berdasarkan data perkembangan jumlah mahasiswa program studi PG PAUD sampai tahun 2017 mengalami peningkatan yang cukup signifikan. Berikut penulis ilustrasikan pada grafik pada gambar 1 . Berdasarkan jumlah mahasiswa pada gambar 1 berikut, hal yang menarik dari data mahasiswa Prodi PG PAUD adalah 99\% jumlah mahasiswanya adalah perempuan. Hal ini wajar mengingat pada umumnya guru TK dan PAUD adalah perempuan. Hal lain yang menarik adalah jumlah mahasiswa berdasarkan usianya.

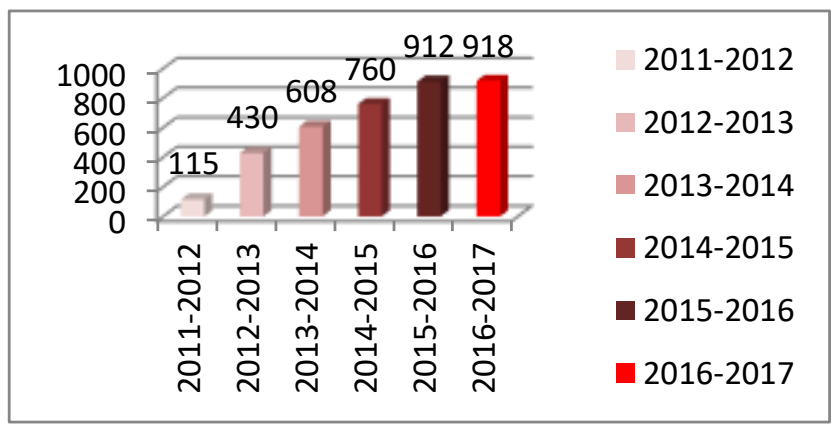

\section{Gambar 1 \\ Jumlah Mahasiswa Prodi PG PAUD Per Tahun Akademik}

Berdasarkan data pada program studi, diketahui bahwa jumlah perbandingan mahasiswa per tahun akademik 2016-2017 berdasarkan usianya penulis tampilkan pada tabel berikut ini.

Tabel 1

Data Mahasiswa Berdasarkan Rentang Usia dan Tahun Kelahiran

\begin{tabular}{|c|c|c|}
\hline \multirow{2}{*}{$\begin{array}{c}\text { Rentang Tahun } \\
\text { Kelahiran }\end{array}$} & $\begin{array}{c}\text { Jumlah } \\
\text { Mahasiswa }\end{array}$ & \multirow{2}{*}{ Rentang Usia } \\
\cline { 2 - 3 } & $\%$ & \\
\hline $1960-1969$ & 20 & $57-48$ \\
\hline $1970-1979$ & 40 & $47-38$ \\
\hline $1980-1989$ & 18 & $37-28$ \\
\hline $1990-1995$ & 22 & $27-22$ \\
\hline
\end{tabular}

Berdasarkan data pada tabel 1 di atas, dapat diketahui bahwa sebagian besar kondisi mahasiswa program studi PG PAUD di rentang usia 48 sampai 57 tahun sebanyak $20 \%$ dan usia rentang 38 sampai 47 sebanyak $40 \%$. Berdasarkan hal tersebut, maka dapat disimpulkan bahwa peminat 
Prodi PG PAUD justru kebanyakan adalah mahasiswa yang termasuk usia dewasa. Yang menarik disini adalah biasanya mahasiswa yang kuliah adalah pada usia 20 sampai 25 tahun namun lain kenyataannya dengan Prodi PG PAUD yang pada umumnya di usia 48 sampai 57 tahun. Hal ini menurut penulis penting untuk diteliti mengenai motivasi dan latar belakang mahasiswa usia dewasa yang mengikuti perkuliahan di Prodi PG PAUD FKIP Uninus Bandung.

Masa dewasa awal menurut Santrock (2003) dimulai pada akhir usia belasan atau permulaan usia 20an dan berlangsung sampai usia 30an. Masa ini merupakan waktu untuk membentuk kemandirian pribadi dan ekonomi. Levinson (dalam Monks dan Knoers, 2006) menjelaskan masa dewasa awal dimulai pada usia 17 tahun hingga 45 tahun. Dalam hal ini Hurlock (1990: 246), membagi masa dewasa menjadi tiga periode, yaitu masa dewasa awal (18 - 40 tahun), masa dewasa madya (40 - 60 tahun) dan masa dewasa akhir (60 - Meninggal).

Pada masa dewasa lanjut, kemampuan fisik maupun psikologis mengalami penurunan yang sangat cepat, sehingga seringkali individu tergantung pada orang lain. Timbul rasa tidak aman karena faktor ekonomi yang menimbulkan perubahan pada pola hidupnya.

Motivasi menurut Greenberg dikutip oleh Djali juga mengemukakan motivasi merupakan "proses membangkitkan, mengarahkan, dan memantapkan perilaku kearah suatu tujuan (Djaali, 2011: 101) Pengertian lain dari motivasi menurut $\mathrm{Mc}$ Donald yang dikutip Wasty Soemanto, "motivasi sebagai perubahan tenaga di dalam diri seseorang yang ditandai oleh dorongan efektif dan reaksi-reaksi mencapai tujuan (Soemanto, 1998: 206).

Ada beberapa fungsi motivasi yang terkait dengan pendidikan diantaranya mendorong manusia untuk berbuat, jadi sebagai penggerak atau motor yang melepaskan energi. Motivasi dalam hal ini merupakan motor penggerak dari setiap kegiatan yang akan dikerjakan (Soemanto, 1998: 85). Motivasi berfungsi untuk sebagai pendorong usaha dan pencapaian prestasi. Dengan adanya usaha yang tekun dan terutama didasari adanya motivasi, maka seseorang yang belajar itu akan dapat melahirkan prestasi yang baik. (Sulistyawati, 2015).

Ada beberapa faktor yang mempengaruhi mahasiswa termotivasi untuk melanjutkan studi ke perguruan tinggi (kuliah). Sebagaimana dalam penelitian Khoiriyah dkk diantaranya ada delapan faktor, yaitu lokasi, faktor biaya, produk, latar belakang sosial ekonomi, motivasi, fasilitas, referensi, promosi, dan reputasi. (Khoiriyah dkk, 2013: 24-32).

Berdasarkan kajian di atas, maka rumusan masalah penelitian yang diungkap dalam bentuk beberapa pertanyaan penelitian sebagai berikut.

1. Bagaimana latar belakang pendidikan mahasiswa usia dewasa yang mengikuti perkuliahan Prodi PG PAUD FKIP Uninus?

2. Bagaimana motivasi mahasiswa usia dewasa yang mengikuti perkuliahan Prodi PG PAUD FKIP Uninus?

3. Apa saja yang menjadi alasan dan tujuan utama mahasiswa usia dewasa mengikuti perkuliahan Prodi PG PAUD FKIP Uninus?

\section{METODE PENELITIAN}

Adapun metode yang digunakan penulis dalam penelitian ini adalah metode penelitian deskripti . Metode penelitian deskriptif adalah salah satu metode penelitan yang banyak digunakan pada penelitian yang bertujuan untuk menjelaskan suatu kejadian. Seperti yang dikemukakan oleh Sugiyono (2011) "penelitian desktiptif adalah sebuah penelitian yang bertujuan untuk memberikan atau menjabarkan suatu keadaan atau fenomena yang terjadi saat ini dengan menggunakan prosedur ilmiah untuk menjawab masalah secara aktual". Sedangkan, Sukmadinata (2012) menyatakan bahwa metode penelitian deskriptif adalah sebuah metode yang berusaha mendeskripsikan, menginterpretasikan sesuatu, misalnya kondisi atau hubungan yang ada, pendapat yang berkembang, proses yang sedang 
berlangsung, akibat atau efek yang terjadi atau tentang kecenderungan yang sedang berlangsung.

Desain penelitian deskriptif lebih condong pada metode pengunaannya, mana penelitian deskriptif ini merupakan proses panjang untuk mengumpulkan fakta harus sesuai dengan interpretasi data-data yang tepat. Dalam penelitian ini peneliti mempergunakan data penelitian yang diambil dari kegiatan, aktivitas, hubungan, serta dampak yang ada dalam masyarakat.

Langkah-langkah pengembangan rancangan penelitian deskriptif meliputi mengidentifikasi dan memilih masalah yang akan diteliti, merumuskan dan mengadakan pembatasan masalah, melakukan kajian pustaka, membuat asumsi atau anggapananggapan, menentukan populasi, sampel, teknik sampling, menentukan instrumen, teknik pengumpulan data, analisis data dan menarik kesimpulan atau generalisasi. Langkah-langkah penelitian ini penulis gambarkan pada gambar 1 berikut.

\section{Teknik Pengumpulan Data}

Untuk memperoleh data yang obyektif, maka ditentukan pula teknik pengumpulan data. Menurut Lofland seperti yang dikutip oleh Moleong (2007:175) sumber data utama dalam penelitian kualitatif adalah "kata-kata dan tindakan, selebihnya adalah data tambahan seperti dokumen dan lain-lain". Peneliti menggunakan teknik pengumpulan data diantaranya adalah wawancara, observasi dan studi dokumentasi. Adapun sebagai rincian pengumpulan data yang dimaksud sebagai berikut :

1. Wawancara

Menurut Moleong (2007:186)

"Wawancara merupakan percakapan dengan maksud tertentu. Percakapan tersebut dilakukan oleh dua pihak yaitu pewawancara (interviewer) yang mengajukan pertanyaan dan terwawancara (interviewe ) yang memberikan jawaban atas pertanyaan itu". Agar mempermudah peneliti dalam mendokumentasikan berbagai data dan informasi yang disampaikan dari informan, maka hasil wawancara di rekam dalam vioce

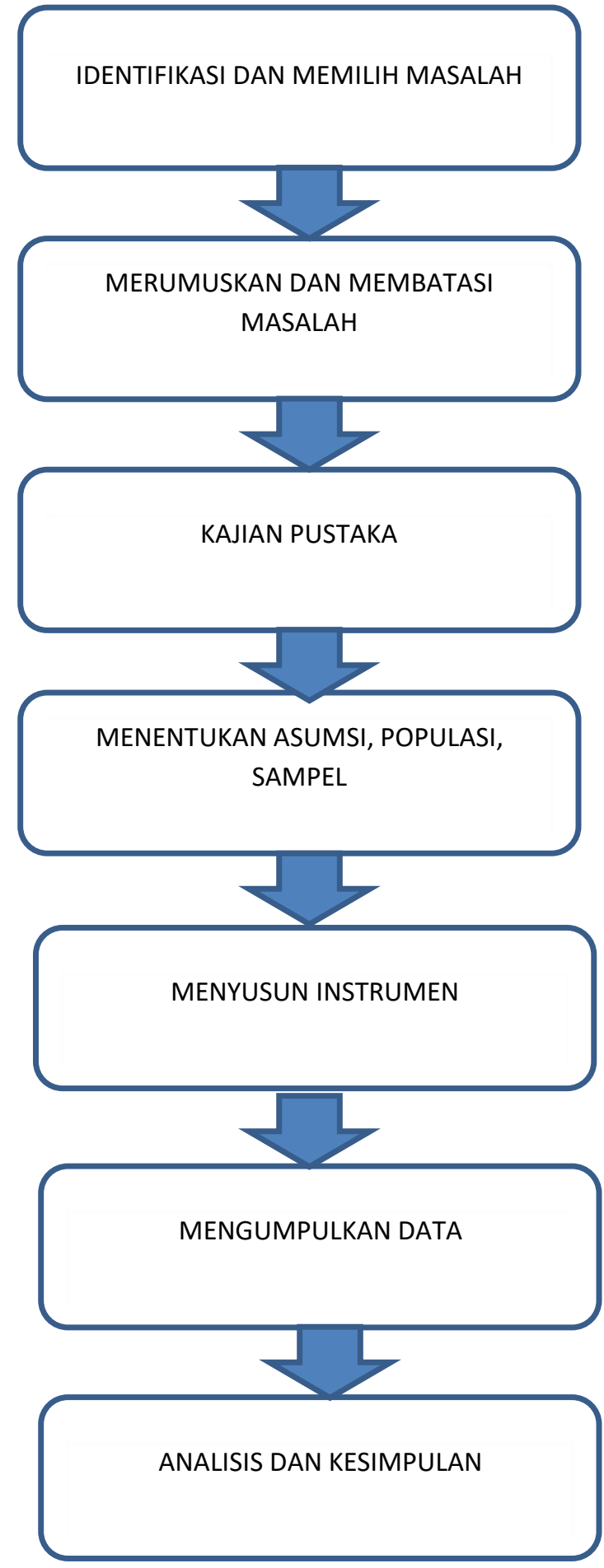

\section{Gambar 1}

Langkah-langkah Penelitian

recorder, camera digital dan atau handphone.

Pada penelitian ini pengumpulan data dilakukan dengan mewawancarai mahasiswa program studi PG PAUD, Dosen 
Pengajar serta Pimpinan Program Studi PG PAUD.

Wawancara yang akan dilakukan adalah wawancara yang bersifat terstruktur, dengan menggunakan pedoman wawancara yang berisi daftar pertanyaan untuk mempermudah peneliti dalam melakukan wawancara. Selanjutnya sebagai bentuk pendalaman informasi dilakukan wawancara bebas, namun isinya tetap berkaitan dengan motivasi dan latar belakang mahasiswa usia dewasa mengikuti perkuliahan di Prodi PG PAUD.

2. Observasi

Menurut Nasution dalam Sugiyono (2008:310) bahwa observasi adalah dasar semua ilmu pengetahuan. Para ilmuan hanya dapat bekerja berdasarkan data, yaitu fakta mengenai kenyataan yang diperoleh melalui observasi. Observas dilakukan guna menggali data tentang motivasi mahasiswa dalam mengikuti perkuliahan di FKIP Uninus.

3. Studi dokumentasi

Studi dokumentasi (docomentary study) adalah suatu teknik data dengan menghimpun dan menganalisis dokumendokumen baik tertulis yang sudah diterbitkan resmi Kementrian Pendidikan dan kebudayaan atau, dokumen gambar, maupun elektronik. Studi dokumen dalam penelitian ini bermaksud menelaah dokumen-dokumen yang telah ada. Pada penelitian ini dokumen yang akan diteliti berupa; data mahasiswa usia dewasa mengikuti perkuliahan di Prodi PG PAUD yang diperoleh melalui bagian pendaftaran dan operator Feeder Program Studi PG PAUD.

\section{Teknik Analisis Data}

Analisis data dilakukan sepanjang penelitian dilaksanakan dan mengacu pada model analisis data kualitatif menurut pendapat Miles dan Huberman (1992: 16) yang mengemukakan langkah analisis data yang terdiri atas tiga alur, yakni: reduksi data, penyajian data, dan penarikan kesimpulan. Hal yang sama pun diungkapkan Nasution (1988:129-130), yang mengemukakan langkah-langkah analisis data sebagai berikut:
1. Reduksi Data: data yang diperoleh di lapangan ditulis/ditik dalam bentuk uraian atau laporan terperinci. Laporan yang disusun kemudian direduksi, dirangkum, dipilih hal-hal pokok, difokuskan pada hal-hal yang penting dan dicarikan temanya.

2. Display Data: data yang telah diperoleh diklasifikasikan menurut pokok permasalahan dan dibuat dalam bentuk matriks sehingga memudahkan peneliti untuk melihat hubungan suatu data dengan data yang lainnya.

3. Mengambil Kesimpulan dan Verifikasi: peneliti membuat kesimpulan berdasarkan data yang telah diproses melalui reduksi dan display data.

\section{HASIL DAN PEMBAHASAN}

\section{Motivasi Mahasiswa Usia Dewasa Yang Mengikuti Perkuliahan}

Untuk mempermudah kegiatan penelitian ini peneliti menggunakan teknik pengumpulan data yaitu dengan teknik wawancara dan atau angket yang dilakukan baik secara tatap muka secara langsung maupun angket dan wawancara dalam bentuk daring untuk mengetahui sejauh mana motivasi mahasiswa usia dewasa mengikuti perkuliahan di Prodi PG PAUD FKIP Uninus.

Peneliti menggunakan instrumen berupa pertanyaan-pertanyaan yang sifatnya terbuka, artinya mahasiswa bisa memberikan jawaban seluas-luasnya tanpa dibatasi dengan indikator-indikator tertentu. Untuk mendapatkan data mengenai motivasi mahasiswa mengikuti perkuliahan di Prodi PG PAUD FKIP Uninus peneliti mengajukan beberapa pertanyaan pokok sebagai instrumen dalam penelitian ini setelah melakukan pengumpulan data baik secara daring maupun secara tulisan penulis peneliti merangkum beberapa jawaban dari para sumber data yang sudah diverifikasi.

Berdasarkan jawaban dari para responden tersebut, mengenai apa saja halhal yang melatarbelakangi para mahasiswa untuk mengikuti atau melanjutkan perkuliahan di Prodi PG PAUD Uninus, dari jawaban-jawaban yang sudah dituliskan di 
atas maka peneliti dapat mengelompokkan beberapa jawaban tersebut menjadi beberapa kelompok.

Kelompok pertama, hal yang melatarbelakangi mahasiswa mengikuti dan atau melanjutkan kuliah di Prodi PG PAUD Uninus antara lain adalah pada umumnya karena kebutuhan linieritas baik secara individu maupun linieritas dalam arti di tempat kerja. Inilah yang menjadi alasan mayoritas para mahasiswa mengikuti atau melanjutkan kuliah. Hal ini memang wajar mengingat sebagaimana yang dijelaskan di awal bahwa pada umumnya mahasiswa usia dewasa ini bahkan $25 \%$ menyatakan sudah mengajar 15 tahun atau lebih sehingga wajar kalau mereka di lapangan sudah bisa dianggap sebagai guru yang senior. Namun karena dari sisi ijazah mereka tidak linier atau bahkan belum memiliki ijazah S1 apapun sehingga mereka dituntut untuk melanjutkan kuliah ke S1 PAUD.

Ada dua macam dalam hal ini, yang pertama mereka yang ingin ijazahnya linier adalah biasanya mahasiswa yang berstatus sebagai PNS atau yang sudah sertifikasi bagi yang golongan mereka masih belum IVa sehingga mereka diwajibkan untuk linier. Adapun kelompok yang lainnya lagi adalah karena memang mereka sama sekali belum memiliki ijazah apapun sehingga mereka langsung melanjutkan ke program studi S1 PG PAUD baik untuk kepentingan pribadi supaya mereka bisa linier bisa sertifikasi ataupun kepentingan kelembagaan karena syarat untuk keberlanjutan sebuah lembaga taman kanak-kanak atau Paud atau TK adalah salah satunya harus ada guru yang sudah memiliki gelar sarjana atau S1 khususnya dari jurusan PAUD.

Kelompok kedua merupakan kelompok dimana alasan mereka mengikuti perkuliahan di Prodi PG PAUD Uninus diantaranya adalah karena kepentingan profesi mereka dalam hal ini hampir mirip dengan kelompok yang pertama di mana mereka dituntut oleh pimpinan lembaga Yayasan atau kepala sekolah untuk segera memiliki ijazah S1 karena konsekuensinya jika mereka masih berstatus sebagai jasa SMA atau Diploma atau S1 namun tidak linier sehingga mereka secara karir secara posisi terancam oleh guru-guru yang lain dengan alasan profesionalitas dan kualifikasi. Berdasarkan hal itu maka kelompok yang kedua ini alasan mengikuti dan melanjutkan perkuliahan di Prodi PG PAUD adalah karena tuntutan profesi dan kebutuhan di tempat kerja sehingga secara tidak langsung hal ini memaksa mereka untuk melanjutkan kuliah

Adapun kelompok yang ketiga adalah kelompok yang peneliti menyebutnya adalah kelompok ideal. Ideal dalam hal ini adalah alasan mengikuti perkuliahan bukan karena alasan pragmatis, tetapi lebih kepada alasan-alasan yang sifatnya idealis. Mahasiswa kelompok ini memberikan alasan hal-hal yang melatarbelakangi mengikuti perkuliahan di Prodi PG PAUD antara lain karena dengan alasan ingin menambah ilmu pengetahuan, supaya otaknya bisa berkembang dengan menambah ilmu ke PAUDan dan kemudian alasan lain adalah dengan alasan senang dengan dunia anak sehingga ingin berkecimpung lebih dalam lagi terhadap dunia anak. Adapun alasan lain yang tergolong kategori ini adalah alasan karena memang ada beberapa mahasiswa yang bercita-cita menjadi seorang guru termasuk guru PAUD dengan alasan karena senang dengan dunia bermain anak.

Alasan lainnya yang menjadikan melatarbelakangi mahasiswa mengikuti perkuliahan di Prodi PG PAUD adalah karena keluarga atau saudara mereka yang terlebih dahulu sudah memiliki lembaga pendidikan berupa TK, RA, Kober, PAUD sehingga pihak keluarga atau saudaranya meminta mahasiswa tersebut untuk melanjutkan ke jenjang yang sesuai dengan kebutuhan di keluarganya yaitu meneruskan pekerjaan orang tuanya sebagai pendidik di PAUD atau Kober atau RA.

\section{Alasan memilih Kuliah di Bidang PAUD/ TK}

Berdasarkan hasil pengumpulan data mengenai pertanyaan tentang apa saja atau apa alasannya mahasiswa tersebut memilih kuliah di bidang PAUD dan tidak memilih bidang yang selain PAUD. Berdasarkan angket yang telah diisi oleh 
sumber data penelitian dari 76 mahasiswa dapat diketahui bahwa mereka memilih kuliah di bidang PAUD karena kebutuhan mereka di tempat kerja mereka sendiri. Artinya pemilihan bidang kuliah ini bukan berdasarkan minat atau motivasi lainnya tetapi lebih karena mereka sebelum masuk ke perkuliahan mereka terlebih dahulu sudah bekerja sebagai guru honor di RA, TK, Kober atau pun PAUD di lingkungan masing-masing. Dengan hal itu maka mereka mahasiswa lebih tertarik untuk memilih bidang PAUD sebagai tempat mengikuti perkuliahan.

Alasan lainnya mengenai mengapa para mahasiswa memilih bidang PAUD hal ini alasannya hampir sama dengan pertanyaan yang disampaikan pada bagian sebelumnya yakni alasan mereka adalah karena mereka para mahasiswa atau keluarganya sudah memiliki lembaga pendidikan seperti TK, Kober, Paud atau RA, sehingga dengan latar belakang tersebut keluarganya meminta agar para mahasiswa ini mengambil jurusan atau perkuliahan yang berkaitan dengan PAUD. Karena untuk kepentingan melanjutkan perkembangan atau keberlanjutan lembaganya masing-masing.

Alasan lainnya yang

melatarbelakangi sehingga mereka memilih kuliah di bidang PAUD antara lain karena dengan alasan ingin menambah ilmu atau ingin mengembangkan ilmu atau ingin mengasah ilmu tentang pendidikan anak usia dini di jenjang perkuliahan sehingga ketika para mahasiswa sudah kembali ke masyarakat mereka bisa menerapkan ilmu tentang PAUD yang sudah diperoleh di bangku perkuliahan Adapun sebagian kecil jawaban dari mahasiswa Mengapa mereka memilih bidang PAUD untuk melanjutkan perkuliahan karena dengan alasan linieritas yakni bagi sebagian dosen sebagian guru PNS mereka wajib melanjutkan ke jenjang pendidikan yang sesuai dengan tuntutan mereka yaitu di bidang PAUD terutama bagi mereka yang berstatus sebagai PNS yang sudah tersertifikasi dan selebihnya Mereka ingin meningkatkan golongan kepegawaian kepada yang lebih tinggi atau bahkan mereka ingin suatu saat bisa menjadi pengawas di daerah masing-masing.

\section{Cita-Cita Yang Memotivasi Melanjutkan Kuliah di Bidang PAUD/ TK}

Pertanyaan yang dilontarkan dalam soal wawancara ini yaitu menanyakan mengenai cita-cita dari para mahasiswa ini sehingga mereka memilih Prodi PAUD sebagai tempat kuliah. Berdasarkan hasil pengumpulan data dari 76 Sumber data penelitian dapat diketahui bahwa sebagian besar bahkan sekitar $90 \%$ yang menyatakan bahwa memang alasan yang menjadikan termotivasi untuk kuliah di bidang Paud atau TK adalah karena pada dasarnya sejak kecil atau sejak mulai usia dewasa sudah berniat menjadi seorang guru namun dalam hal ini karena sumber-sumber data tidak menyebutkan jenis guru bidang Paud atau jadi guru bidang lain. Dengan demikian dapat disimpulkan bahwa pemilihan peminatan untuk prodi PAUD merupakan atas dasar cita-cita sejak kecil memang ingin menjadi guru walaupun tidak spesifik ingin jadi guru PAUD.

Berdasarkan jawaban dengan sumber data yang lainnya, mengapa mereka memilih menjadi guru PAUD atau menekuni profesi guru PAUD karena sebetulnya citacita mereka menjadi guru didukung karena kondisi keluarga atau orang tua yang sebelumnya sudah memiliki lembaga pendidikan TK Paud Kober atau RA sehingga para mahasiswa semakin termotivasi untuk melakukan studi di bidang PAUD. Selain jawaban tersebut ada beberapa jawaban lainnya yang termasuk kategori jawaban yang minoritas. Alasan yang minoritas ini diantaranya adalah alasan yang lebih praktis misalnya seperti ingin terdaftar sebagai guru yang tersertifikasi atau ingin menjadi PNS atau ada sebagian yang ingin menjadi ahli di bidang PAUD baik sebagai dosen ataupun sebagai praktisi. Ada juga yang menyatakan mereka memilih cita-cita menjadi guru karena memang sudah merasa ada bahkan ketika kecil atau mungkin ketika di sekolah. Selain itu dalam konteks lain cita-cita mahasiswa ini adalah memilih Prodi PAUD yaitu ingin menjadi 
guru yang kompeten dan profesional dalam rangka mencerdaskan kehidupan bangsa.

\section{Keuntungan Yang Mungkin diperoleh Ketika Memilih Menjadi Guru}

Pada pertanyaan nomor 5 ini, peneliti berusaha menggali mengenai hal-hal yang dianggap menguntungkan bagi para mahasiswa yang memilih profesi sebagai guru khususnya menjadi guru PAUD. Berdasarkan hasil wawancara yang diberikan kepada 76 Mahasiswa dapat diketahui bahwa sebagian besar atau pada umumnya hal-hal yang dianggap sebagai sebuah keuntungan dari profesi menjadi guru adalah karena faktor kepuasan batin. Artinya keuntungan menurut mereka bukan dilihat dari sisi pragmatis materi gaji atau tunjangan, tetapi lebih kepada kepuasan batin karena bisa memberikan pendidikan bagi warga masyarakat di sekitar tempat tinggalnya.

Alasan lain yang dianggap menjadikan guru sebagai adalah profesi yang menguntungkan adalah ada beberapa mahasiswa yang lebih pada faktor kehormatan artinya profesi guru Memang secara finansial tidak menjanjikan tetapi dalam lingkup masyarakat bergaul mereka menganggap profesi guru lebih dihargai lebih dihormati lebih disegani oleh masyarakat sehingga hal itu menurut para mahasiswa adalah salah satu faktor yang menguntungkan berprofesi sebagai guru khususnya guru PAUD.

Adapun alasan lain yang memang masih cukup mayoritas antara lain adalah karena faktor niat dalam hati atau faktor kepuasan batin ingin mengamalkan ilmu dan berbagi di masyarakat khususnya bagi anakanak usia PAUD di sekitar tempat tinggalnya sehingga mereka bisa berbagi ilmu berbagi cerita dengan anak-anak di sekitar tempat tinggalnya.

Selain itu keuntungan lain yang dianggap lebih oleh para mahasiswa adalah menjadi guru merupakan profesi yang waktunya fleksibel sehingga mereka bisa tetap mengurus keluarga di rumah bisa tetap mengabdi masyarakat juga bisa sebagai tenaga pendidik atau guru. Hal ini berkorelasi dengan kenyataan bahwa guru guru PAUD rata-rata adalah perempuan, sehingga profesi guru PAUD itu cocok dengan perempuan. Maka wajar guru PAUD atau mahasiswa di Prodi PG PAUD ke mayoritas adalah mahasiswi

Adapun hal lain yang dianggap sebagai sebuah keuntungan adalah pada dimensi religius. Artinya mereka yang profesi sebagai guru tidak hanya sekedar rutinitas biasa tapi mereka menganggap bahwa mengajar mendidik anak adalah merupakan hal yang sangat dianjurkan oleh Allah dan rasulnya sehingga mereka menganggap bahwa mengajar adalah suatu hal yang dapat mendatangkan pahala bagi orang yang mengajarnya sehingga hal ini menjadi nilai daya tarik atau hal yang dianggap menguntungkan bagi profesi sebagai guru karena menganggap bahwa menjadi guru manfaatnya tidak hanya di dunia tapi juga di akhirat kelak

\section{Hal yang Dianggap Sebagai Kerugian Menjalani Profesi Guru}

Pada pertanyaan ini peneliti ingin mengungkap mengenai hal-hal apa saja yang dianggap sebagai kerugian menjalani profesi sebagai guru khususnya guru PAUD. Berdasarkan hasil wawancara kepada 76 mahasiswa usia dewasa dapat diketahui bahwa mayoritas mahasiswa tidak menyatakan adanya kerugian bagi mereka yang berprofesi sebagai guru. Namun demikian tidak adanya kerugian itu adalah apabila mengajar dengan jujur ikhlas serta tidak mengharap upah yang besar.

Jawabannya lainnya yang dianggap menjadikan kerugian sebagai profesi guru PAUD antara lain adalah dari sisi materi. Mahasiswa menganggap bahwa kerugian menjadi guru PAUD Adalah gaji yang sangat kecil bahkan di bawah rata-rata guru pada umumnya. Berdasarkan hasil penelusuran gaji guru PAUD rata-rata di kisaran Rp300.000 sampai 1 juta itupun tergantung TK nya masing-masing bahkan ada guru yang gajinya diberikan secara rapel setiap 3 bulan sekali atau bahkan ada guru yang tidak jelas jadwal penerimaan honornya. Itulah yang menjadi salah satu kerugian menjadi guru PAUD. 
Selain itu, menurut pengakuan para mahasiswa kerugian mereka berprofesi sebagai guru PAUD adalah sulitnya untuk mendaftar menjadi CPNS atau diangkat menjadi PNS. Kerugian lain yang dianggap menjadi beban bagi para guru PAUD antara lain adalah karena desakan atau karena desakan dari orang tua murid yang menganggap pembelajarannya tidak berhasil misalnya karena anak belum bisa berhitung atau belum bisa membaca. Kemudian kendala lainnya kerugian lainnya adalah ada beberapa orang tua yang tidak mau mengikuti mekanisme yang ada di sekolah walaupun pada dasarnya orang tua sudah mempercayakan proses pembelajaran kepada guru di sekolah tetapi seringkali kritik-kritik yang keras disampaikan pada orang tua kepada guru.

Selain itu kerugian menjadi guru PAUD menurut para mahasiswa antara lain adalah karena pemerintah atau pihak berwenang saat ini dianggap belum memperhatikan kesejahteraan atau tunjangan guru PAUD sehingga dengan itu mereka berharap bahwa pemerintah atau dinas terkait bisa membuat regulasi mengenai perbaikan kesejahteraan atau tunjangan bagi para guru TK atau PAUD.

\section{SIMPULAN}

Hal-hal yang melatarbelakangi mahasiswa usia dewasa untuk mengikuti perkuliahan atau melanjutkan kuliah di Prodi PG PAUD FKIP Uninus antara lain adalah karena kebutuhan untuk linieritas. Dalam hal ini dibagi menjadi dua pertama ada kelompok mahasiswa yang sama sekali belum memiliki ijazah sarjana sehingga mereka harus memiliki ijazah S1 agar bisa melanjutkan pekerjaannya sebagai guru, kelompok yang berikutnya adalah mereka yang guru honorer atau PNS tetapi secara keahlian belum linier sehingga mereka dituntut untuk melanjutkan kuliah di bidang Paud atau TK. Selain itu, ada pula alasan lain yakni karena biasanya keluarga atau orang tua dari pada mahasiswa usia dewasa ini sudah memiliki lembaga TK atau ra atau Paud di tempat tinggalnya masing-masing sehingga orang tua mahasiswa ini mengharapkan ada generasi penerus untuk melanjutkan keberlangsungan penyelenggaraan Paud atau Kober atau TK tersebut.

Terdapat beberapa alasan mengapa mahasiswa usia dewasa memilih kuliah di bidang PAUD atau TK dan para mahasiswa ini tidak memilih bidang lainnya alasan yang dikemukakan antara lain pada umumnya adalah karena kebutuhan di tempat kerja mereka masing-masing. Karena pada umumnya mereka sudah bekerja sejak 15 tahun yang lalu sehingga jelas lembaga mereka sangat membutuhkan tenaga ahli guru di bidang PAUD. Alasan lain yang mendukung para mahasiswa ini untuk menekuni bidang PAUD antara lain karena mereka keluarganya atau orang tuanya sudah memiliki lembaga sebelumnya sehingga dituntut untuk melanjutkan kuliah di bidang yang sesuai dengan keperluan yaitu bidang PAUD sedangkan alasan lainnya yaitu meliputi ketertarikan minat serta kesenangan para mahasiswa ini untuk berkecimpung di dunia anak atau Paud. Dari 76 mahasiswa ada beberapa sebagian mahasiswa yang menjadikan bahwa kuliah di PG PAUD itu adalah untuk meningkatkan Golongan atau naik golongan bagi guru yang berstatus PNS supaya menjadi meningkat golongannya menjadi golongan yang lebih tinggi

Pendapat beberapa alasan mengapa mahasiswa usia dewasa memilih mengikuti perkuliahan di Prodi PG PAUD FKIP Uninus alasan yang paling umum antara lain karena faktor jarak tempuh dari tempat tinggal mahasiswa yang relevan atau dianggap kampus yang paling dekat sebagaimana diketahui bahwa mahasiswa usia dewasa ini berstatus juga sebagai guru di sekolahnya masing-masing sehingga dengan jarak yang dekat memungkinkan mereka untuk mengikuti perkuliahan. Alasan lain yang menjadikan mahasiswa usia dewasa memilih Prodi PG PAUD FKIP Uninus adalah karena masalah teknis pembiayaan yakni pembiayaan bisa dilakukan dengan cara dicicil sehingga ini dianggap meringankan bagi para mahasiswa. Alasan lain di antaranya adalah karena di Prodi PG PAUD FKIP Uninus terdapat kelas non reguler. Kelas non reguler ini yang membuat ketertarikan para mahasiswa 
karena bisa kuliah dengan menyesuaikan waktu kerja masing-masing. Kelas non reguler ini bisa mereka ikuti setelah mereka mengajar di sekolah masing-masing. Alasan lainnya yang menjadikan mahasiswa tertarik untuk kuliah di Prodi PG PAUD FKIP Uninus antara lain karena adanya tawaran beasiswa baik dari internal kampus maupun beasiswa dari pihak dinas pemerintah provinsi Jawa Barat dinas kabupaten atau kota Bandung atau dari instansi lainnya yang relevan sesuai dengan program beasiswa.

\section{SARAN}

Berdasarkan paparan sebelumnya, ada beberapa rekomendasi yang peneliti berikan kepada pihak-pihak terkait, diantaranya pihak sekolah, pihak FKIP Uninus, dan dinas pendidikan terkait.

Pihak sekolah, kepala sekolah ataupun Yayasan hendaknya mendukung dan memberikan motivasi kepada para guru yang belum memiliki gelar sarjana atau yang belum linier untuk melanjutkan pendidikan ke jenjang sarjana khususnya untuk Prodi PG PAUD baik di Uninus ataupun di tempat lainnya.

Kepada pihak FKIP Uninus hendaknya membuat regulasi khusus mengenai mekanisme perkuliahan khusus untuk mahasiswa usia dewasa yang sudah bekerja sebagai guru. Regulasi yang dimaksud bisa dalam bentuk regulasi keuangan atau regulasi model perkuliahan yang sekaligus mendukung profesi mereka sebagai guru sehingga kesempatan bagi mereka untuk mengikuti perkuliahan guna linieritas itu akan lebih terbuka.

Pihak dinas pendidikan terkait hendaknya memberikan berbagai sosialisasi akan pentingnya linieritas bagi guru yang belum memenuhi kualifikasi khususnya bagi guru guru PAUD yang ada di daerah atau pelosok agar melanjutkan pendidikan ke jenjang sarjana. Dalam hal ini Dinas Pendidikan setempat idealnya bisa memfasilitasi agar mereka para guru yang belum linier bisa mendapatkan kesempatan untuk mengikuti perkuliahan.

\section{DAFTAR PUSTAKA}

Abdorrakhman, Ginting. 2008. Esensi Praktis Belajar dan Pembelajaran, Bandung: Humaniora.

Dimyati dan Mudjiono. 2009. Belajar dan Pembelajaran, Jakarta: Rineka Cipta.

Djaal., 2011. Psikologi Pendidikan. Jakarta: Bumi Aksara.

Hurlock, E. B. 1990. Psikologi Perkembangan: Suatu Pendekatan Sepanjang Rentang Kehidupan. Alih Bahasa: Soedjarwo dan Iswidayanti. Jakarta: Erlangga

Khoiriyah, D., Susilawati, M., \& Nilakusmawati, D. P. E. 2013. Faktor-Faktor Yang Memengaruhi Minat Mahasiswa Asal Luar Bali Kuliah di FMIPA Universitas Udayana Bali. EJurnal Matematika. Vol. 2,No. 1,Januari 2013, 24-32.

Meleong, 2007, Metodologi Penelitian Kualitatif, Bandung : PT. Remaja Rosdakarya.

Miles, M. B dan Huberman, A. M. 1992. Analisis Data Kualitatif. Jakarta. Universitas Indonesia Press.

Nasution, S. 1988. Metode Penelitian Naturalistik Kualitatif. Bandung: Tarsito

Purwa, Atmaja Prawira. 2012 Psikologi Pendidikan dalam Perspektif Baru, Yogyakarta: Ar Ruz Media.

Santrock, J. W. 2003. Perkembangan Remaja, Jakarta; Erlangga.

Sugiyono, 2007, Memahami Penelitian Kualitatif, Bandung : Alfabeta

Soemanto, W. 1998. Psikologi Pendidikan, Jakarta: Rineka Cipta.

Sukmadinata, N. S. 2012. Metode Penelitian Pendidikan. Bandung: PT. Remaja Rosdakarya.

Sulistyawati, H. 2015. Hubungan Antara Motivasi Menjadi Bidan dengan 
Jurnal PG-PAUD Trunojoyo : Jurnal Pendidikan dan Pembelajaran Anak Usia Dini,

Volume 5, Nomor 2, Oktober 2018, hal 75-85

Prestasi Belajar Asuhan

Kebidanan Ibu Hamil pada

Mahasiswa Semester II Prodi DIII

Kebidanan (Studi di Stikes Icme

Jombang). Jurnal Insan Cendekia.

Vol. 2 No. 1. 